\title{
NEGARA HUKUM, PROGRAM LEGISLASI NASIONAL DAN KEBUTUHAN DESAIN BESAR BAGI PERENCANAANNYA
}

\author{
Bambang Kesowo \\ Kejaksaan Agung Republik Indonesia \\ (alamat email)
}

\begin{abstract}
The question of whether the State of Indonesia is a State law have to answered by using indicators of justice for everyone without any discrimination, rule of law through the establishment of laws, also respect and protection of human rights. Indonesian Constitution of 1945 in Article 1 paragraph (3) states that "Indonesia is a State of Law". Indonesian rule of law, based on Pancasila as a state ideology, the 1945 Constitution as a constitution, the Unitary Republic of Indonesia as an absolute choice of the state form, and the principle of national unity (bhineka tunggal ika) as a unifying element throughout the nation. The process of forming legislation would be a step toward the ideal state of law, where the planning, community participation, and the law making process by open discussion conducted at legal establishment.
\end{abstract}

Keyword : Rule of law, Legislation program, Plan desain

\begin{abstract}
Abstrak
Pertanyaan apakah Negara Indonesia adalah sebuah Negara hukum harus dijawab dengan menggunakan indikator penegakan keadilan bagi setiap orang tanpa ada pembeda, kepastian hukum melalui pembentukan peraturan perundang-undangan, dan penghormatan serta perlindungan terhadap hak-hak asasi manusia. UUD NRI 1945 pada Pasal 1 ayat (3) menyatakan bahwa "Negara Indonesia adalah Negara Hukum”. Negara hukum Indonesia berdasar pada Pancasila sebagai ideologi bangsa, UUD 1945 sebagai konstitusi, NKRI sebagai pilihan mutlak bentuk negara, dan prinsip bhineka tunggal ika sebagai penyatu seluruh elemen bangsa. Proses pembentukan peraturan perundang-undangan yang baik merupakan satu langkah menuju cita negara hukum, dimana perencanaan, partisipasi masyarakat, dan proses pembahasan yang terbuka dilakukan saat pembentukan hukum.
\end{abstract}

Kata Kunci : Negara hukum, Program legislasi, Desain perencanaan

\section{Latar Belakang}

Sudah lebih sepuluh tahun terakhir ini reformasi kehidupan nasional berlangsung, tetapi seperti halnya masa-masa jauh sebelumnya, wacana dan debat sekitar negara hukum ini juga masih saja tak kunjung usai. Sementara soal arti, makna dan tujuan konsepsi negara hukum diurai dan dijelaskan dengan panjang lebar dalam ruang perkuliahan dan berbagai buku, yang muncul dalam kehidupan sehari-hari masyarakat adalah pertanyaan yang seakan- akan bergeser dan melompat. Yang diinginkan adalah jawaban atas pertanyaan: benar-benar negara hukumkah Negara Kesatuan Republik Indonesia ini? Kapankah hal itu akan dapat terwujud? Setelah lebih dari 60 tahun menggantungkan cita tersebut, berapa lama lagi harus ditunggu perwujudannya?

Mengapa pertanyaan soal tersebut demikian bergeser dan melompat? Berbagai kejadian dalam kehidupan masyarakat yang sesungguhnya, seakan-akan memberi kesan bahwa antara 
kenyataan yang berlangsung dan makna yang dijelaskan bagi sebuah negara hukum, tersekat jurang pemisah yang lebar. Beberapa contoh ketika hukum bekerja dengan cepat dalam kasus pencurian tiga butir kakao, piring, hingga sandal jepit, tetapi lamban ketika menghadapi perbuatan pidana yang berkaitan dengan penyelenggara kekuasaan, seolah mempersilakan orang untuk melihat, membaca dan memengertinya sendiri.

Esensi tentang kepastian hukum, keadilan, ataupun "due process" bukan saja tidak hadir secara nyata ketika kejadian demi kejadian tadi berlangsung, melainkan dikatakan malah belum dapat dirasakan. Hukum dikatakan bagai pisau yang tajam kalau mengiris ke bawah, tetapi tumpul kalau harus menancap ke atas. Sindiran lain yang sejenis itu, juga semakin luas menyeruak. Demikian banyak contoh yang terjadi dalam kehidupan akhir-akhir ini, telah dieksploitasi untuk mengungkap seolah-olah fungsi negara absen ketika ditunggu: "Negara tidak hadir ketika warganya memerlukan”; "Negara dapat dan telah berjalan sendiri tanpa penyelenggara, atau negara autopilot”.

Ungkapan "Negara tanpa wibawa" juga meluncur ketika berbagai bentuk dan cara mengungkap rasa tidak puas kian cenderung mengabaikan aturan dan rusuh. Sewaktu pertikaian massa secara horisontal ataupun dengan aparat makin lazim terjadi, atau ketika unjuk rasa yang disertai kekerasan dan perusakan berlangsung tanpa tindakan apapun dari pemerintah atau negara, atau malah dihadapi dengan tindakan keras dari aparat keamanan, ungkapan yang terdengar: "yang diperlukan saat ini bukan hukum, tetapi keadilan". Begitulah ungkapan-ungkapan yang terdengar kian sarkastik selama ini.

Bilamana demikian besarnya pergeseran dan lompatan pertanyaan tadi, adakah hal itu merupakan cerminan tentang belum mapannya konsepsi negara hukum itu? Ataukah perkembangan demi perkembangan nilai dan tafsir dalam konsep itu sendiri, yang membuat kita lambat mencerna dan menjabarkannya? Ataukah berbagai gejolak dalam kehidupan kenegaraan kita di masa lalu, yang membuat kita bagai tidak memiliki waktu yang cukup untuk mengendapkan dan menjabarkannya?

Pemahaman terhadap konsepsi negara hukum ternyata memang bukan proses yang cepat dan sekali tuntas. Mahfud dengan panjang lebar menutur perbedaan asal usul dan pergeseran pemahaman sekitar konsepsi tentang Rechtsstaat dan Rule of Law yang dalam bahasa Indonesia diterjemahkan secara sama sebagai Negara Hukum1, dijelaskannya bagaimana setelah amandemen yang ketiga, UUD 1945 tidak lagi mengisyaratkan cita negara hukum dengan tampilan kata Rechtsstaat, melainkan melalui perumusan Pasal 1 ayat (3) bahwa "Negara Indonesia adalah Negara Hukum”. Dari sudut konsepsi, langkah tersebut dapat dikatakan maju dalam perumusan. Dalam istilah yang digunakan Mahfud, selain mengusung konsep prismatik2, rumusan tersebut netral karena tidak menyebut lagi rechtsstaat maupun rule of law. Melalui kesempatan lain, Mahfud memakai ungkapan “... mendekatkan atau menjadikan rechtsstaat dan the rule of law sebagai konsep yang saling komplementatif dan konvergentif. Konsep negara hukum Indonesia menerima prinsip kepastian hukum yang menjadi hal utama dalam konsepsi rechtsstaat, sekaligus juga menerima prinsip rasa keadilan dalam the rule of law.”3

Sampai pada ujung yang sama tetapi bertolak dari uraian yang berbeda, sesungguhnya baik bila kita tengok sejenak bagaimana sesungguhnya sudut pandang mereka yang tumbuh dan besar di masyarakat yang hidup dalam alam Rule of Law itu. Fletcher, mahaguru ilmu hukum dari Universitas Columbia menengarai bahwa dalam pemahaman masyarakat yang berbahasa Inggris, kata 'Law' pada Rule of Law mengandung dua makna yang dibedakan dalam paham dan bahasa bangsabangsa di Eropa. Law dapat bermakna Gesetz (Jerman) atau Loi (Perancis), atau Ley (Spanyol) yang bermakna aturan yang ditetapkan, disahkan, dan diundangkan oleh organ yang berwenang, dan Law dalam arti Right, atau Recht (Jerman), atau Droit (Perancis), atau Derecho (Spanyol) yang sama artinya dengan aturan yang baik atau adil.

1 Moh. Mahfud, MD., Membangun Politik Hukum, Menegakkan Konstitusi, Rajawali Press, Jakarta, 2011; hlm. $24-27$.

2 Ibid, hlm. 26 ... "Negara Hukum Indonesia yang berdasarkan Pancasila dan UUD 1945 mengambil konsep prismatik atau integratif dari dua konsepsi tersebut sehingga "kepastian hukum” dalam Rechtsstaat dipadukan dengan prinsip "keadilan” dalam the Rule of Law. Indonesia tidak memilih salah satunya tetapi memasukkan unsur-unsur baik dari keduanya” ...

3 Moh. Mahfud, MD, Revitalisasi Pancasila Sebagai Cita Negara Hukum, Orasi ilmiah didepan Rapat Senat Terbuka dalam rangka Dies Natalis ke-65 Fakultas Hukum Uni=versitas Gadjah Mada, Yogyakarta, 17 Februari 2011. 
Karenanya, kalau Rule of Law dimaknai sebagai pemerintahan yang penyelenggaraannya diikat oleh atau didasarkan pada aturan yang dibuat, ditetapkan dan diundangkan sebelumnya, maka sandarannya adalah aturan yang dibuat oleh badan yang berwenang membuatnya, tidak penting apakah aturan itu baik atau tidak. Sebaliknya bila Rule of Law dimaknai sebagai penyelenggaraan pemerintahan negara yang baik, sandarannya adalah aturan yang baik dan adil tadi, yang dalam istilah Fletcher disebut "law in the high sense".

Di Amerika Serikat, masih kata Fletcher, tidak pernah benar-benar diyakini, pada pemahaman yang mana sesungguhnya makna 'Law' dalam Rule of Law tersebut harus diacukan. UUD Amerika Serikat tidak berbicara sepatah pun soal itu. Bilamana Mahfud mengatakan bahwa pada akhirnya Rechtsstaat dan Rule of Law beroperasi pada substansi yang sama yaitu pada perlindungan atas hak-hak asasi manusia ${ }^{5}$, Fletcher juga berujar bahwa ditengah ketiadaan acuan tadi, analogi yang paling dekat adalah prinsip dalam UUD tentang larangan "deprevation of life, liberty, or property without due process of law". Anggapan tentang "due process" itulah yang meletakkan dasar pemahaman terbaik mengenai prinsip tentang "right" dan "justice". ${ }^{6}$

Kalaupun sekarang cita tentang negara hukum telah ditegaskan dalam UUD 1945, dan secara ideal dan ilmiah akan dibangun di atas keseimbangan konsepsi baik Rechtsstaat maupun Rule of Law, pertanyaan yang menunggu adalah, bagaimana kira-kira perwujudan dan operasionalisasinya. Konkritnya, bagaimana mengupayakan keseimbangan di antara keduanya, antara prinsip kepastian hukum dan keadilan, tanpa terjebak dalam eksesifitas Gesetzstaat yang dikenali dengan pengagungan dan pengutamaannya terhadap aturan (baca: undang-undang)—bahkan tanpa peduli baik atau buruk-, dan dipihak lain eksklusifitas Rule of Law yang dikenali sangat berorientasi pada mekanisme peradilan berikut yurisprudensinya dan kekhawatiran terhadap lahirnya "no-law-state" ?

\section{Pembahasan}

Bilamana perwujudan cita negara hukum yang ber-esensikan keseimbangan seperti tadi yang akan kita kembangkan, memang demikianlah mestinya. Pelajaran dari pengalaman kita sendiri selama demikian banyak tahun dalam kehidupan bernegara, ataupun pelajaran yang sama yang diperoleh bangsa-bangsa lain, juga menunjukkan perlunya hal itu. Rasanya belum pernah ada negara, baik yang bertumpu pada konsepsi Rechtsstaat yang mengutamakan kepastian hukum, maupun yang bertumpu pada konsepsi Rule of Law yang mengutamakan keadilan dan "due process", yang tahan dan secara konsisten mampu secara murni berjalan hanya di atas konsepsi masing-masing.

Kehidupan manusia berikut sistem nilai yang dianut terus bergerak dan bahkan berubah dengan cepat. Negara-negara yang sedari awal tumbuh dan hidup di atas tradisi Rule of Law juga tidak mengklaim, bahwa ide untuk menegakkan keadilan lantas berarti segala sesuatunya dapat dipecahkan melalui otoritas dan mekanisme peradilan. Mereka mengakui, banyak patokan dan tuntunan—apalagi yang menyangkut hak-hak dan aturan main yang bersifat dasar atau asasi-harus diteguhkan panduannya melalui undang-undang. Kalaupun mengambil sebagai misal praktik kehidupan Amerika Serikat dalam pembuatan undang-undang, produktivitas Kongres selaku otoritas pembuat undang-undang, jumlah undangundang yang dibuatnya setiap tahun tidaklah kalah dibandingkan Indonesia, yang dari mulanya malah hidup dan beroperasi dengan konsepsi Rechtsstaat. Seandainya pun contoh diperlebar dengan Inggris dan Australia, situasi dan kondisinya tidaklah berbeda jauh dari Amerika Serikat.

Sesungguhnya persoalan sekitar pemahaman cita negara hukum ibaratnya sudah diantar secara teori hingga ke ujung. Cita negara hukum sebenarnya memang bukan soal bentuk atau format. Cita Negara hukum pada intinya adalah soal esensi. Cita negara hukum adalah cita bahwa penyelenggaraan negara termasuk pemerintahannya harus selalu dilandaskan dan berpe-

4 George P. Fletcher, Basic Concepts of Legal Thought, Oxford University Press, New York-Oxford, 1996; hlm. 12-13.

5 Moh. Mahfud MD, op cit, hlm. 25.

6 George P. Fletcher, op cit, hlm. 13: "Unlike typical European constitutions, the basic charter of the United States says nothing about a commitment to the rule of law. The closest constitutional analogue is the phrase prohibiting the deprevation of 'life, liberty, or property without due process of law', 
gang pada aturan yang baik dan berkeadilan. Persoalan pokok yang kemudian memerlukan jawaban adalah, bagaimana mewujudkan tatanan aturan dan mekanismenya, bagaimana mentransformasi semangat keadilan ke dalam aturan yang dibuat, dan bagaimana pula mengoperasionalkan mekanisme peradilan yang mampu memberi dan menjamin keadilan tadi.

Moh. Mahfud mengungkap pikirannya bahwa: "Sebagai cita hukum, Pancasila sekaligus menjadi bingkai bagi sistem hukum Pancasila, sebagai sistem khas Indonesia yang berbeda dari sistem hukum lain. Pancasila merupakan konsep prismatik yang mengasimilasikan segi-segi baik dari berbagai konsep dan tumbuh menjadi konsep tersendiri yang selalu diaktualkan dengan realitas dan perkembangan masyarakat Indonesia. Pancasila sebagai cita hukum menjadikan hukum Indonesia bukan merupakan hukum yang sekuler dan juga hukum yang hanya didasarkan pada agama tertentu saja. Dalam perspektif sistem hukum, Pancasila menjadikan sistem hukum Indonesia berbeda dengan mengambil sisi baik dari konsep Rechtsstaat maupun the Rule of Law. Pancasila harus menjadikan tujuan keadilan substansial (substantive justice) dan kepastian hukum (procedural justice). Dalam proses penegakan hukum, harus ada kepastian hukum bahwa keadilan ditegakkan”.

Untuk negara seperti Negara Kesatuan Republik Indonesia yang sedari awal dibangun dengan konsepsi Rechtsstaat, bagaimana gambaran kehidupan pilar-pilar tadi sampai sekarang ini? Dalam data di Sekretariat Kabinet ${ }^{8}$, jumlah peraturan perundang-undangan yang meliputi bentukbentuk yang selama ini dikenal seperti undangundang, peraturan pemerintah pengganti undangundang, peraturan pemerintah, dan peraturan (sebelumnya dinamakan keputusan) presiden, tercatat 16.584. Belum termasuk dalam jumlah tersebut adalah peraturan-peraturan yang ditetapkan pemerintah Hindia Belanda, yang berdasarkan kekuatan Pasal I Aturan Peralihan UUD 1945 (pasca amandemen) masih dinyatakan tetap diberlakukan hingga ditetapkannya peraturan yang baru untuk menggantikannya. Dari jumlah tadi, pencacahan jumlah yang berupa undang- undang saja, dan inventarisasi statusnya yang ada dan masih berlaku sejak kemerdekaan, belum sama di antara lembaga atau instansi.

Untuk konteks efektivitas pelaksaanan dan penegakan, mungkin jumlah bukan soal yang penting. Sebaliknya jelas akan menjadi masalah dalam pelaksanaan dan penegakannya bila tidak ada kepastian atau ketepatan data tentang berapa dan mana yang masih berlaku atau tidak berlaku lagi. Begitu pula dengan tidak adanya catatan yang benar mengenai berapa dan yang mana peraturan masa pra kemerdekaan yang kini masih berlaku dan yang tidak berlaku lagi. Pengadministrasian peraturan perundang-undangan, katakanlah pencacahannya, inventarisasi, pencatatan, pendokumentasian dan pengundangannya-dalam bentuk dan dengan sistem apapun dalam kemajuan teknologi informatika hal itu dapat saja dipilih_-bagaimanapun merupakan sesuatu yang mutlak. Tampak sebagai hal yang sepele, sederhana dan tampak seakan hanya fungsi klerek, selama ini memang masih dipandang rendah dalam dunia kepegawaian. Banyak orang malu melakukannya, karena pekerjaan tersebut dianggap tidak bergengsi. Orang ingin dikatakan bahwa ialah bidan, ialah desainer, ialah perancang atau istilah menterengnya drafter.

Orang ingin dilihat sebagai "pembuat". Selain penguasaan kebijakan yang akan diatur, penguasaan mendalam mengenai substansi keilmuannya, keahlian dalam teknik perancangan atau drafting, tidaklah akan pernah seseorang dapat menjadi "pembuat" yang baik tanpa penguasaan pekerjaan yang tampaknya sepele tadi. Tanpa pemahaman tentang aturan-aturan yang telah ada, atau yang berkaitan dan harus diperhatikan, penempatan dan cara penemuannya kembali, tidak ada orang yang dapat menjadi bidan atau konseptor, atau pembuat peraturan perundang-undangan yang baik. Keberadaan tenaga-tenaga ahli dan cakap seperti itu sangat penting, baik di kalangan lembaga pemerintah maupun-dan terutama-di DPR sebagai lembaga yang mengusung kekuasaan membuat undang-undang.

Sesungguhnyalah perlu, dalam sistem pendidikan atau pelatihan tenaga di bidang pembuatan dan pengadministrasian peraturan perundang-

7 Moh. Mahfud MD, Revitalisasi Pancasila Sebagai Cita Negara Hukum, Orasi dalam rangka Dies Natalis ke-65 Fakultas Hukum Universitas Gadjah Mada, Yogyakarta, 17 Februari 2011; hlm. 10-11.

8 Sekretariat Kabinet RI, Informasi perundang-undangan, http://www.setkab.go.id, 2012. 
undangan ini, di samping pengenalan terhadap prosedur perancangan termasuk penguasaan teknik drafting, mewajibkan setiap calon tenaga perancang tersebut untuk memulai penugasan dengan penguasaan aspek dokumentasi dan penemuan kembali ini. Baru setelah itu, pelatihan dilakukan dengan memberi kesempatan untuk bekerja di bidang perencanaan kebijakan, guna memberi dasar penguasaan lingkup kebijakan yang dikelola instansinya. Keahlian yang dipupuk dari awal secara benar itulah yang nantinya menentukan kualitas aturan apapun yang dibuat.

Pengalaman dan kenyataan menunjukkan betapa banyak undang-undang yang begitu diundangkan, dan bahkan belum mulai dilaksanakan, langsung diikuti masalah di belakangnya. Apapun bentuk masalah dan sebabnya, yang kemudian banyak terlihat adalah tidak berjalan baiknya undang-undang yang disahkan. Ada yang masih harus menunggu dibuatnya peraturan pelaksanaan, ada yang harus diubah lagi terlebih dahulu, atau bahkan dibatalkan dalam proses pengujian di Mahkamah Konstitusi, meski dalam hal yang terakhir ini juga perlu dicermati munculnya semacam kegenitan demokrasi dengan menggunakan Mahkamah Konstitusi sebagai ajang.

Semua itu tadi baru menyangkut bagian kecil saja masalah dalam proses pembuatan. Bagian lain yang sama pentingnya dalam keseluruhan kegiatan pengadministrasian dalam arti luas setiap peraturan perundang-undangan adalah kemampuan dalam pelaksanaan atau implementasinya. Mensosialisasikan, menyebarluaskan pemahaman setidaknya latar belakang, prinsipprinsip dan arah atau tujuan yang ingin dicapai, adalah sangat penting. Sebagai salah satu pilar, masyarakat adalah pengguna dan sekaligus pihak yang terkena. Adanya pemahaman yang baik di kalangan masyarakat akan berpengaruh besar bagi efektivitas peratuan perundang-undangan, atau katakanlah undang-undang, atau bahkan hukum dalam arti yang lebih luas lagi.

Anggapan hukum bahwa setiap orang dianggap mengetahui hukum, dalam perspektif sistem hukum ini, hanya akan berjalan baik, efektif dan adil bilamana dibarengi dengan pelaksanaan penyebarluasan pemahaman terhadap hukum itu sendiri. Sosialisasi atau penyebarluasan pemahaman menjadi penting karena bagaimanapun masyarakat adalah "stake-holder" utama. Pemahaman yang memadai itu pula - bila kata "baik" dianggap terlalu utopis-yang antara lain akan memberikan cermin yang obyektif, bilamana muncul penilaian apakah implementasi peraturan perundang-undangan memenuhi rasa keadilan atau tidak. Bagaimanapun, keadilan adalah nilai yang hidup dan berkembang seiring dengan gerak kehidupan itu sendiri. Keadilan tidak hanya harus tercermin dalam prinsip-prinsip dan substansi peraturan perundang-undangan ketika dibuat, tetapi juga ketika diimplementasikan.

Sama pentingnya dengan pemahaman di kalangan masyarakat, bahkan kualitas penguasaan yang lebih baik, adalah pemahaman di kalangan aparat penegak hukum. Sosialisasi dan pemberian pelatihan peraturan perundang-undangan yang banyak jumlahnya, memang bukan pekerjaan yang ringan. Namun memilah dan memilih mana yang harus dipahami dan dikuasai, jelas bukan pemecahan yang tepat. Yang harus dihadapi, adalah cara dan bentuk program sosialisasi dan pelatihannya. Bukankah semua peraturan harus dilaksanakan dengan efektif? Mendahulukan yang satu dan mengemudiankan yang lain dapat saja dibedakan, misalnya terhadap peraturan perundang-undangan yang tidak memerlukan daya paksa atau ancaman pidana terhadap masyarakat pada umumnya seperti misalnya soal APBN dan perubahan atau tambahannya, pembentukan lembaga, pemekaran atau pembentukan pemerintah daerah, atau pembentukan pengadilan di daerah. Atau peraturan perundang-undangan yang hanya berisi norma kebijakan-yang sebenarnya tidak begitu layak dituangkan dalam bentuk undang-undang - tetapi akhir-akhir ini semakin banyak dibuat. Hanya dengan pemahaman dan penguasaan yang baik di kalangan aparat penegak hukum, proses penegakan hukum dapat berjalan baik.

Sering terdengar ungkapan, hukum yang baik dan adil lahir dari proses dan acara yang baik. Sedikit terbalik, Lyons berujar "proses hukum yang baik akan mendorong sikap hormat dan ketaatan terhadap hukum". ${ }^{9}$ Lebih dari itu, dengan 
pemahaman yang baik di kalangan aparat penegak hukum khususnya di lingkungan badan peradilan, elaborasi prinsip-prinsip yang dituangkan dalam peraturan perundang-undangan atau pengembangannya sesuai dengan cepatnya perubahan dalam kehidupan masyarakat berikut nilai-nilai di dalamnya, dapat dilakukan dengan tepat dan adil. Singkatnya, hanya kalau tiga pilar sistem hukum tadi berjalan dengan baik, sistem hukum berjalan baik pula.

Namun di antara tiga pilar tadi yang saat ini perlu diberi perhatian dalam kaitannya dengan esensi negara hukum, adalah pilar aturan tadi. Aspek kepastian hukum jelas penting dan harus dipenuhi. Tetapi dengan menyimak kenyataan bahwa kehidupan masyarakat berikut nilai yang dikandung di dalamnya juga bergerak dan berubah dengan cepat, muncul pertanyaan yang sangat memerlukan jawaban kita: seberapa jauhkah kemampuan kita untuk membuat, mengubah atau mengganti aturan guna memberi kepastian hukum di dalamnya? Seperti tadi telah disinggung, bila aspek kepastian hukum harus dicerminkan sepenuhnya dan semata-mata pada kehadiran aturan tertulis saja, rasanya tidak ada negara yang tahan dan bahkan mampu berkejaran dengan waktu dan perubahan untuk memenuhinya. Selama reformasi sejak 1999 sampai dengan akhir 2011 yang lalu di Sekretariat Negara RI tercatat 460 undang-undang10. Sekalipun demikian, tetap saja masih banyak lagi undang-undang yang masih harus diselesaikan dan masih akan dibuat. Bagaimanapun, hal itu memang merupakan satu opsi. Opsi lainnya, dan ini sejajar pula dengan pemahaman tentang keseimbangan atau perpaduan antara kepastian hukum dalam konsepsi Rechtsstaat dan keadilan yang diusung konsepsi Rule of Law, adalah menumbuhkembangkan paham bahwa tidak semua hal perlu diatur dalam undang-undang secara rinci atau detail, dan tidak semua hal perlu diatur dengan undang-undang.

Undang-undang sebaiknya hanya untuk mengatur materi dan aspek-aspek yang mendasar, yang pokok dalam kehidupan manusia, dalam hubungan antara manusia dengan manusia atau lembaga, dan hal-hal yang bersifat prinsip dan mendasar dalam penyelenggaraan kehidupan berbangsa dan bernegara, serta penyelenggaraan hubungan dengan bangsa dan negara lainnya. Hal-hal yang bersifat elaboratif dan kecabangan, dibiarkan berkembang dalam praktik kehidupan masyarakat dan diserahkan pada mekanisme peradilan untuk menyelesaikannya sesuai dengan perkembangan nilai dan rasa keadilan yang hidup dalam masyarakat. Senang atau tidak, realita itulah yang sekarang dan nanti harus kita hadapi dan kita bangun. Keberanian untuk merombak paradigma dan cara pikir yang ada hingga saat ini, akan diperlukan untuk menjawab persoalan tersebut.

Pertanyaan berikutnya, yang manakah hal-hal yang bersifat pokok dan mendasar dalam kehidupan bangsa yang perlu diatur dalam atau dengan undang-undang itu? Sebelum menjawab pertanyaan tersebut, sebaiknya dicermati, berlanjutnya anggapan dan cara fikir bahwa undangundang dapat digunakan untuk menyelesaikan apa saja termasuk yang praktis sifatnya, apalagi sekadar alat untuk mempertahankan kekuasaan, atau bahkan mengatur hal-hal yang detail sifatnya, sesungguhnya hanya akan semakin menyulitkan terwujudnya cita negara hukum kita. Kondisi semacam itu juga hanya akan menghadirkan tatanan kehidupan yang semu. Banyaknya undangundang yang dibuat tetapi dengan pengadministrasian yang lamban, dan substansi yang lemah dan kebanyakan dibatalkan dalam tahap pengujian, bukanlah prestasi yang bermanfaat. Yang tampil hanya sekadar hiruk pikuk penyusunan program legislasi yang membebani anggaran negara.

Beberapa prinsip dalam pembentukan peraturan perundang-undangan seperti diatur dalam Undang-undang Nomor 12 Tahun 2011-yang menggantikan Undang-undang Nomor 10 Tahun 2004-menjadi perlu untuk dipikirkan ulang. Jenis dan hierarki, fungsi serta materi muatan, sebagai misal. Di samping soal lingkup materi yang diarahkan dalam Pasal 10 Undang-undang Nomor 12 tadi, bagaimana kira-kira konsep mengenai jangkauan materi pengaturan, ketika menyangkut batasan bahwa hanya hal-hal yang bersifat pokok dan mendasar saja yang perlu diatur.

Begitu pula bagaimana kira-kira arah penataan ulang fungsi beberapa peraturan di bawah undang-undang, khususnya peraturan pemerintah dan peraturan daerah: bagaimana lingkup 
materi muatannya, dan seberapa jauh jangkauan pengaturan yang dapat dilakukan untuk hal-hal yang teknis dan detail, terutama yang menyangkut penyelenggaraan hubungan antar kehidupan manusia dan atau lembaga. Semuanya memerlukan pemikiran ulang. Sama pentingnya dengan pembenahan prinsip dalam pembentukan peraturan perundang-undangan tadi adalah kemungkinan pembenahan aspek kewenangan badan-badan peradilan berikut aturan mengenai acara yang diperlukan, mengingat akan menjadi luasnya fungsi badan-badan tersebut.

Bagaimana dengan pembentukan undangundang? Selain soal batasan jangkauan materi, persoalan penting yang rasanya sangat perlu diperhatikan adalah mengenai perencanaan itu sendiri. Pertama, arahan tentang materi muatan dalam Pasal 10 ayat (1) Undang-undang Nomor 12 Tahun 2011 seperti untuk pengaturan lanjut ketentuan UUD (huruf a), untuk melaksanakan perintah undang-undang terdahulu (huruf b), atau untuk pemenuhan kebutuhan hukum dalam masyarakat (huruf e), sangat luas pengertiannya dan belum memberi batasan tentang bidang ataupun batasan jangkauan pengaturannya. Kedua, arahan tentang perencanaan dalam Program Legislasi Nasional (Prolegnas) seperti diberikan dalam Pasal 16-23, lebih banyak mengatur aspek prosedural atau formal, dan belum memberikan arahan dan tuntunan aspek substantif atau materiil, yang dapat dengan tepat memberikan acuan pikir yang sama tentang apa saja yang sebenarnya harus dibuat atau masih harus dibuat, mana yang harus diubah/disempurnakan/diganti, serta kapan itu semua harus diselesaikan. Sekiranya hal yang terakhir ini dapat diwaspadai, maka Prolegnas akan sekaligus menggambarkan sebuah Politik Perundang-undangan, yang akan menjawab pertanyaan pokok tentang undang-undang apa yang yang perlu dan seharusnya dibuat, mengapa demikian, apa yang harus diatur dan arah yang dituju, dan kapan harus diwujudkan.

Diperlukan sebuah desain besar yang dapat menjadi acuan bersama bagi penyusunan rencana dalam prolegnas tersebut. Desain yang sekaligus merupakan peta dasar dan rambu ukur untuk menetapkan apa saja yang sebenarnya diperlukan. Desain yang memberikan tuntunan dalam penentuan prioritas bagi proses pembuatan dan penyelesaiannya. Desain yang dari sisi kiri ke arah kanan mampu memberikan gambaran pokok tentang tujuan nasional yang digariskan dalam UUD 1945, dan terjabar dalam aspek-aspek dasar kehidupan negara dan bangsa yang menyangkut budaya, sosial, ekonomi, politik, dan keamanan nasional. Masing-masing aspek tersebut pada gilirannya dijabarkan, seperti aspek ekonomi memiliki bidang-bidang antara lain infrastruktur dasar, produksi dan distribusi/pemasaran. Bidang infrastruktur dasar, lagi-lagi sekedar sebagai misal, memiliki aspek manusia, permodalan, teknologi dan seterusnya. Ketika sampai pada aspek permodalan, orang akan berfikir tentang perbankan, perasuransian, pasar modal, serta lembaga keuangan lainnya. Demikianlah, dari arah kiri ke kanan kita akan memiliki peta yang bermula dari amanat pokok UUD hingga memeroleh daftar tugas dan kewajiban negara untuk mengatur dalam Undangundang apa yang diperlukan.

Dari sisi kanan ke arah kiri, sebagai pangkal tolak adalah upaya pembangunan untuk mewujudkan tujuan nasional yang berlandaskan Pancasila sebagai cita hukum, sebagai sumber dari segala sumber hukum. Dari arah kanan ditegaskan sasaran pokok pembangunan yang berintikan manusia dan seluruh masyarakat Indonesia yang seutuhnya : batiniah, dan lahiriah. Jabaran sasaran tadi kearah kiri menjangkau aspek aspek dasar dalam kehidupan manusia dan masyarakat yaitu budaya, sosial, politik, ekonomi, dan keamanan. Sebagai misal, jabaran aspek ekonomi kehidupan manusia menyangkut hak dan kebutuhan untuk memperoleh penghasilan, pekerjaan, memiliki kekayaan dan seterusnya. Aturan apa yang diperlukan untuk menjamin terwujudnya setiap aspek tersebut, dapat dipikirkan dan dirumuskan bersama. Pertemuan jabaran dari dua arah itulah yang akan memberikan peta aturan apa yang dibutuhkan, apa yang sudah dimiliki, apa yang perlu disempurnakan atau diganti. Inti dari semua itu adalah acuan yang sama mengenai kebutuan dan untuk menentukan prioritas pembuatan serta penyelesaiannya.

Keberadaan desain besar atau grand design akan membantu secara substantif agar penyusunan Prolegnas berlangsung lebih obyektif dan rasional. Keberadaannya juga akan dapat menggambarkan secara komprehensif dan jelas apa sebenarnya politik perundang-undangan nasional. Dengan desain seperti itu, pentahapan prolegnas dalam 
rencana tahunan dan penentuan prioritas-nya juga dapat dilakukan dengan lebih baik. Memang harus dicatat, walaupun sangat penting, tetapi Desain besar masih sebatas pada perencanaan prolegnas saja. Bagaimana agar isi atau substansi undangundang dapat menjadi cerminan Pancasila sebagai cita hukum, sehingga operasionalisasinya juga dapat berlangsung dengan semangat keadilan, masih merupakan upaya dan perjuangan tersendiri. Selain kemampuan dan kematangan para perancang, masalah kesamaan pemahaman terhadap Pancasila yang justru menjadi cita hukum ini nyatanya masih saja menjadi persoalan ketika tahap operasionalisasi undang-undang harus berlangsung. Kalaupun keberadaan sebuah undangundang dan ketentuannya dinilai memenuhi harapan sebuah kepastian hukum, tetapi keadilan yang diharapkan dalam penerapannya masih saja tidak mudah diwujudkan.

Sebagian diantara kita banyak yang dapat bersaksi, betapa sejak bertahun-tahun diupayakan pemahaman, aktualisasi dan operasionalisasi Pancasila, tetapi sampai kini pun semua itu belum juga menampakkan hasil yang dapat menjadi pegangan bersama. Karenanya adalah ironi, ketika di era reformasi ini hampir semua bidang kehidupan terjamah gerak perubahan dan pembaharuan, soal yang satu ini justru ditinggalkan. Banyak undang-undang yang secara harfiah menggunakan Pancasila sebagai pertimbangan pembuatannya, atau menyatakan atau mensyaratkan penggunaannya sebagai azas, tetapi kemudian dikritik karena berisikan substansi pengaturan yang justru jauh dari semangat Pancasila sebagai cita hukum. Pemahaman terhadap Pancasila yang mestinya mampu mendorong lahirnya kearifan dalam memberi keadilan, sering tidak hadir ketika diharapkan.

Keadilan, yang menjadi tumpuan dan sekaligus harapan dalam perwujudan cita negara hukum di samping aspek kepastian hukum, tidak akan mudah terwujud dan memperoleh patokan tanpa penyelesaian masalah yang penting ini. Mungkin saja memang tidak perlu lagi harus menggali 36 butir-butir pengertian Pancasila seperti masa lalu, atau memerasnya lagi hingga berlipat dua atau tiga kalinya. Namun cara dan bentuk pemahaman, yang sekalipun hanya dalam garis besar dan pokok tetapi mudah diserap dan dijadikan pegangan, sungguh menjadi tantangan termasuk bagi Fakultas Hukum Universitas Gadjah Mada untuk merintisnya. Cukup dalam garis besar dan pokok-pokok saja, karena penjabarannya dalam rangka mewujudkan keadilan adalah soal interpretasi, yang selain dari waktu ke waktu terus berkembang, juga dapat selalu diuji dalam mekanisme peradilan.

Undang-undang memang produk politik, karena bagaimanapun memang dibuat oleh lembaga politik. Pilihan prinsip-prinsip yang dikandung di dalamnya, juga diputuskan dengan pertimbangan-pertimbangan politik. Namun dengan kehadiran desain besar yang disepakati dan digunakan sebagai acuan bersama, dan berlandaskan pemahaman yang sama pula terhadap Pancasila sebagai cita hukum, setidaknya dominasi keinginan politik yang kurang proporsional dalam proses perencanaan, pembuatan, dan penentuan prioritas penyelesaian undang-undang akan dapat di-rem. Dalih kekuasaan sebagai pembuat undang-undang, dengan adanya desain besar juga tidak dapat dengan semena-mena digunakan untuk mengubah atau mengganti suatu undang-undang hanya karena pelaksanaannya tidak menguntungkan atau kurang sesuai dengan kepentingan politik tertentu.

Rasionalitas yang terbangun dari keberadaan sebuah desain besar adalah terhindarnya prolegnas dari kekurangan selama ini: daftar panjang, tetapi sedikit yang dapat diselesaikan. Dari 247 RUU yang direncanakan DPR dalam Prolegnas 2010-2014, tahun 2010 hanya diselesaikan 13 UU. Dengan menetapkan prioritas sebanyak 91 RUU yang direncanakan dalam Prolegnas 2011-21 di antaranya limpahan dari Prolegnas 2010-diselesaikan 24 UU, dan dari jumlah itupun hanya 20 atau 21,97\% yang merupakan program 2011. Selebihnya berasal dari RUU yang bersifat komulatif terbuka seperti APBN dan pengesahan perjanjian. Sesungguhnyalah, rendahnya produktivitas pembuatan UU tadi, ditengah gurauan "yang ditunggu tidak jadi-jadi, sedangkan yang jadi bukanlah yang ditunggu”, adalah cerminan kelemahan di sektor perencanaan dan belum memadainya tenaga perancang peraturan perundang-undangan baik dalam jumlah maupun dalam kualitas yang diperlukan. 


\section{Kesimpulan}

Demikianlah selintas pandang tentang potret dinamika cita negara hukum kita, bila disisir salah satu pilarnya, aturan hukum khususnya peraturan perundang-undangan, dan lebih khusus lagi undang-undang. Tidak banyak taburan kutipan bagai layaknya kertas karya dan orasi ilmiah, karena sudut pandang berdasar pengalaman terhadap potret dinamika itulah yang didahulukan. Pengalaman pula yang memberikan kemampuan penilaian bagaimana cita, teori dan ilmu berjalan dalam kehidupan yang senyatanya.

\section{DAFTAR PUSTAKA}

Moh. Mahfud MD, Membangun Politik Hukum, Menegakkan Konstitusi,Rajawali Press, Jakarta, 2011.

Antony Allot, The Limits of Law, Butterworths, London-Butterwoths, 1980.

David Lyons, Ethics and The Rule of Law, Cambridge University Press, Cambridge-London-New York-New Rochelle-Melbourne-Sidney, 1984.
George P. Fletcher, Basic Concepts of Legal Thought,Oxdford University Press, New York - Oxford,1996.

\section{Orasi Ilmiah}

Moh. Mahfud MD, Revitalisasi Pancasila Sebagai Cita Negara Hukum, disampaikan pada Rapat Senat Terbuka dalam ranga Dies Natalis ke-65 Fakultas Hukum Universitas Gadjah Mada, Yogyakarta, 17 Februari 2011. 